\title{
Modeling and simulation of inductive-based wireless power transmission systems
}

Mohammad Haerinia

mohammad.haerinia@und.edu

How does access to this work benefit you? Let us know!

Follow this and additional works at: https://commons.und.edu/ee-stu

Part of the Electrical and Computer Engineering Commons

\section{Recommended Citation}

Mohammad Haerinia. "Modeling and simulation of inductive-based wireless power transmission systems" (2018). Electrical Engineering Student Publications. 4.

https://commons.und.edu/ee-stu/4

This Abstract is brought to you for free and open access by the Department of Electrical Engineering at UND Scholarly Commons. It has been accepted for inclusion in Electrical Engineering Student Publications by an authorized administrator of UND Scholarly Commons. For more information, please contact und.commons@library.und.edu. 
Modeling and simulation of inductive-based wireless power transmission systems: Technology, Components and System Design

Mohammad Haerinia

College of Engineering and Mines, University of North Dakota, Grand Forks, USA.

\section{Abstract:}

This chapter studies an inductive-based wireless power transfer system for low-power applications at short distances. The transferring power system has been modeled, simulated and analyzed via finite element method. A wireless power transfer system includes important parts such as coil, core and driver. In this chapter, the important parts of an inductive power transfer system have been analyzed. Receiving and transmitting printed spiral coils are designed in an optimized procedure. The experimental results were in a good agreement with the simulation results. Moreover, based on the performed modulation and simulation the use of the pot core as the receiving core is proposed. It is concluded that this type of core can improve magnetic flux density in the receiving side. Different geometries of coils for transmitting side have been modeled and simulated. An electromagnetic analysis has been done; the experimental result was in a good agreement with the simulation result. This work presents an efficient perspective to coil design.

\section{References}

[1] Inoue, K., Nagashima, T., Wei, X. "Design of High-efficiency Inductive-Coupled Wireless Power Transfer System with Class-DE Transmitter and Class-E Rectifier," Industrial Electronics Society. 39th Annual Conference of the IEEE ,2013,613-618.

[2] Li , S.,Mi , C. C. "Wireless Power Transfer for Electric Vehicle Applications," IEEE Journal of Emerging and Selected Topics in Power Electronics , 2015 Vol. 3, No. 1, 4-17.

[3] Madawala , U. K., Thrimawithana , D. J. "Current sourced bi-directional inductive power transfer system," IET Power Electron, 2011, Vol. 4, No. 4, 471-480.

[4] Abel , E.,Third , S. "Contactless power transfer-An exercise in topology," "IEEE Trans. Magn, 1984, Vol. 20, No. 5, 1813-1815.

[5] Ahn, D., Hong, S. "A Study on Magnetic Field Repeater in Wireless Power Transfer," IEEE Transactions on Industrial Electronics ,2013, Vol. 60, NO. 1,360- 371.

[6] Rajagopalan, A.,RamRakhyani , A., K.Schurig , D., K.Lazzi , G."Improving Power Transfer Efficiency of a ShortRange Telemetry System Using Compact Metamaterials," IEEE TRANSACTIONS ON MICROWAVE THEORY AND TECHNIQUES , 2014, 1-9.

[7] Lee , B.,Kiani , M.“A Triple-Loop Inductive Power Transmission System for Biomedical Applications," IEEE TRANSACTIONS ON BIOMEDICAL CIRCUITS AND SYSTEMS, 2015, 1-11.

[8] Imura , T.,Hori , Y."Maximizing Air Gap and Efficiency of Magnetic Resonant Coupling for Wireless Power Transfer Using Equivalent Circuit and Neumann Formula," IEEE TRANSACTIONS ON INDUSTRIAL ELECTRONICS, 2011,Vol. 58, No. 10 4746-4752.

[9] Pinuela, M.,Yates , D., C.Lucyszyn , S.,Mitcheson , P, D."Maximising DC to Load Efficiency for Inductive Power Transfer," IEEE TRANSACTIONS ON POWER ELECTRONICS, 2012, 1-11.

[10] Covic, B., G., A., Boys, J., T. "Inductive Power Transfer," Proceedings of the IEEE, 2013,Vol. 101, No. 6. [11] Ivitz, L., Vinko, D., Švedek, T. "Wireless Power Transfer for Mobile Phone Charging Device," PMIPRO , 2012,141-145.

[12] Mühlethaler, J.,Kolar , J., W.Bosshard, R."Optimized Magnetic Design for Inductive Power Transfer Coils," Proceedings of the 28th Applied Power Electronics Conference and Exposition (APEC) , 2013.

[13] Madzharov, N., D., Tonchev , A., T."INDUCTIVE HIGH POWER TRANSFER TECHNOLOGIES FOR ELECTRIC VEHICLES," Journal of ELECTRICAL ENGINEERING, 2014,Vol. 65, No. 2, 125-128.

[14] Mou , X.,Sun , H. "Wireless Power Transfer: Survey and Roadmap," 2015 IEEE 81st Vehicular Technology Conference (VTC Spring) , 2015, 1-5.

[15] Kallel , B.,Keutel , T.Kanoun, O."Miso configuration efficiency in inductive power transmission for supplying wireless sensors," 11th International Multi-Conference on (SSD) , 2014, 1-5.

[16] Mühlethaler , J.,Kolar , J., W., Ecklebe , A. "A Novel Approach for 3D Air Gap Reluctance Calculations," 8th International Conference on Power Electronics - ECCE Asia, 2011, 446-452.

[17] Ferrites and accessories , EPCOS data book, 2013.

[18] Prasanth, V., Wireless Power Transfer for E-Mobility ,M.S. thesis, faculty of electrical engineering, mathematics and computer science electrical power processing, delft university of technology, Delft,Netherlands, 2012. 
[19] Xie , L.,Shi , Y.Hou , Y. T.,Lou , W. "Wireless power transfer and applications to sensor networks ," IEEE Wireless Communications, 2013, Vol. 20, No. 4, 140-145.

[20] Jow , U.,Ghovanloo , M.“Design and Optimization of Printed Spiral Coils for Efficient Transcutaneous Inductive Power Transmission," IEEE TRANSACTIONS ON BIOMEDICAL CIRCUITS AND SYSTEMS , 2008, Vol. 1, No. 3, 193-202.

[21] Mohan , S., S.,Hershenson , M.,Boyd, S. P.,Lee , T., H. "Simple accurate expressions for planar spiral inductances," IEEE J. SOLID-STATE CIRCUITS, 1999, Vol. 34, No. 10, 1419-1424.

[22] Provo , C., B. "Magnetic Resonate coupling as a means for Wireless emf transfer," , 2013, 1-8.

[23] Haerinia, M., Afjei, E. "Resonant inductive coupling as a potential means for wireless power transfer to printed spiral coil," Journal of Electrical Engineering ,Romania, 2016,Vol. 16, No. 2.

[24] Duan , C.,Jiang , C.,Taylor, A.,Bai , K. "Design of a Zero - voltage- switching large-air-gap wireless charger with low electric Stress for electric vehicles," Power Electronics, IET, 2013, Vol. 6,1742-1750.

[25] Cannon, B. L.,Hoburg , J. F.Stancil , D. D.,Goldstein , S. C. "Magnetic Resonant Coupling As a PotentialMeans for Wireless Power Transfer to Multiple Small Receivers," IEEE Trans. on Power Electronics , 2009, Vol. 24, No. 7, $1819-1825$.

[26] Ho-Le, K. "Finite element mesh generation methods: A review and classification," Computer-Aided Design, 1988, Vol. 20, No. 1, 27-38.

[27] Elliott , G. A. J.,Boys , J. T.Green , A. W. "Magnetically coupled systems for power transfer to electric vehicles," Proceedings of 1995 International Conference on Power Electronics and Drive Systems, 1995, Vol. 2,797-801.

[28] U day S. Dixit,Finite Element Method: An Introduction, Department of Mechanical Engineering, Indian Institute of Technology Guwahati, India, 2007.

[29] Haerinia, M., Afjei, E. "Investigation of Receiving Pot Core Effect on Magnetic Flux Density in Inductive CouplingBased Wireless Power Transfer," IEEE conference, International Symposium on Power Electronics, Electrical Drives, Automation, and Motion (SPEEDAM 2016),Italy, 2016.

[30] Berglund, R., Frequency Dependence of Transformer Losses ,M.S. thesis, Chalmers University of Technology, Gothenburg, Sweden, 2009.

[31] Apoorva , P.,Deeksha , K. S.Pavithra , N.,Vijayalakshmi , M. N.,Somashekar , B.,Livingston , D. "Design of a Wireless Power Transfer System using Inductive Coupling and MATLAB programming," International Journal on Recent and Innovation Trends in Computing and Communication , 2015, Vol. 3, No. 6, 3817-3825.

[32] Hwang , S. H.,Kang , C. G.Son , Y. H.,Jang , B. J. "Software-Based Wireless Power Transfer Platform for Various Power Control Experiments," Energies , 2015, Vol. 8, No. 8, 7677-7689.

[33] Kiani, M., Wireless Power and Data Transmission to High-performance Implantable Medical Devices,PhD. thesis, Georgia Institute of Technology, USA, 2014.

[34] Chang , R.,Quan , L.Zhu , X.,Zong , Z.,Zhou , H.“Design of a Wireless Power Transfer System for EV Application Based on Finite Element Analysis and MATLAB Simulation," ITEC Asia-Pacific , 2014, 1-4.

[35] Kim , J.,Park , Y. J.“Approximate Closed-Form Formula for Calculating Ohmic Resistance in Coils of Parallel Round Wires With Unequal Pitches," IEEE Trans. on Industrial Electronics , 2015, Vol. 62, No. 6, 3482-3489.

[36] Version 5.1 of COMSOL Multiphysics Software, User Manual , COMSOL Ltd., 2015.

[37] Afjei , E.,Siadatan , A.,Torkaman , H."Analytical Design and FEM Verification of a Novel Three-Phase Seven Layers Switched Reluctance Motor," Progress In Electromagnetics Research , 2013, Vol. 140, 131-146.

[38] Cheshmehbeigi , H. M.,Afjei , E.,Nasiri , B."Electromagnetic Design Based on Hybrid Analytical and 3-D Finite Element Method for Novel Two Layers BLDS Machine ," Progress In Electromagnetics Research , 2013, Vol. 136, 141-155.

[39] Torkaman , H.,Afjei , E."Comparison of Three Novel Types of Two-Phase Switched Reluctance Motors Using Finite Element Method," Progress In Electromagnetics Research , 2012, Vol. 125, 151-164.

[40] Torkaman , H.,Afjei , E."Radial Force Characteristic Assessment in a Novel Two-Phase Dual Layer SRG Using FEM," Progress In Electromagnetics Research , 2012, Vol. 125, 185-202.

[41] Afjei , E.,Torkaman , H."Comparison of Two Types of Dual Layer Generator in Field Assisted Mode Utilizing 3DFEM and Experimental Verification," Progress In Electromagnetics Research B , 2010, Vol. 23, $293-309$.

[42] Torkaman , H.,Afjei , E."FEM Analysis of Angular Misalignment Fault in SRM Magnetostatic Characteristics," Progress In Electromagnetics Research , 2010, PIER. 104, 31-48.

[43] Moradi , H.,Afjei , E.,Faghihi , F."FEM Analysis for a Novel Configuration of Brushless DC Motor without Permanent Magnet," Progress In Electromagnetics Research , 2009, PIER. 98, 407-423.

[44] Esteban, B. A.A Comparative Study of Power Supply Architectures In Wireless Electric Vehicle ChargingSystems ,M.S. thesis, University of Windsor, Windsor, Ontario, Canada, 2014.

[45] Haerinia, M., Mosallanejad, A., Afjei, E. "Electromagnetic Analysis of Different Geometry of Transmitting Coils for Wireless Power Transmission Applications," Progress In Electromagnetics Research M ,USA, 2016,Vol. 50, $161-168$. [46] Haerinia, M., Assessment of New Method for Inductive-Based Wireless Power Transmission System ,M.S. thesis, faculty of electrical engineering, Shahid Beheshti University,Tehran, Iran 2016.

[47] Hasan, N.Optimization and Control of Lumped Transmitting Coil-Based in Motion Wireless Power Transfer Systems ,M.S. thesis, Utah State University, Logan, Utah, 2015. 
[48] Grandi , G.,Kazimierczuk , M. K.Massarini , A.,Reggiani , U. "Stray capacitances of single-layer air-core inductors for high-frequency applications," Industry Applications Conference, 1996. Thirty-First IAS Annual Meeting, IAS '96., Conference Record of the 1996 IEEE , 1996, Vol. 3, 1384-1388.

[49] Schuylenbergh, K. V.,Puers, R., Inductive Powering: Basic Theory and Application to Biomedical Systems , Springer Science, Leuven, Belgium, 2009.

[50] Jimmy Li, C.A Planarized, Capacitor-loaded and Optimized Loop Structure for Wireless Power Transfer , M.S. thesis,University of Texas at Austin, Austin, USA, 2013. 


\title{
ENERGY HARVESTING FOR WIRELESS SENSOR NETWORKS
}

\author{
Technology, Components and System Design
}

Wireless sensor systems are becoming increasingly important in several fields of innovation and technology. Decisive properties are the reduced installation costs, the flexible application, and the low-maintenance operation. For the supply of wireless sensor systems, several basic technologies of energy harvesting and energy transfer are nowadays available reaching a good degree of technical maturity, such as solar converters, vibration converters and thermoelectric converters. Nevertheless, the design of wireless sensor networks needs to consider also important aspects concerning energy consumption, such as energy-aware communication technologies and ultra-low-power electronics. Some challenges arise thereby due to the strong dependence on the application environments ambient energy sources, which show typically different behaviors with regard to availability, reliability and dependence on influencing factors and ambient conditions. In order to retain the functionality of the sensor nodes, both energy input as well as intelligent energy management methods need to be addressed under consideration of the situation based on accurate information about the energy balance and the system operating modes. Nodes need to cooperate together to guarantee a better network availability.

The book gives an actual overview of the state of the art of energy aware sensor networks. The book includes comprehensive contributions for the most important ambient energy sources, such as solar energy, vibration, thermoelectric converters, energy management and energy transmission for the power supply of sensor systems.

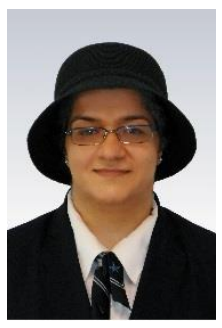

Prof. Dr. Olfa Kanoun is professor for measurement and sensor technology at Chemnitz university of technology. She is specialist in the field of sensors and sensor systems design.

\section{DE GRUYTER
OLDENBOURG}

Olfa Kanoun (Ed.)

ENERGY

HARVESTING

FOR WIRELESS

\section{SENSOR}

\section{NETWORKS}

TECHNOLOGY, COMPONENTS
AND SYSTEM DESIGN

383 pages, 249 Figures,

44 Schedule

\section{Paperback:}

RRP * $€[D] 89.95$ / *US\$ 103.99 /

${ }^{*}$ GBP 82.00

ISBN 978-3-11-044368-4

eBook:

RRP *€ [D] 89.95 / *US\$ 103.99 /

*GBP 82.00

PDF ISBN 978-3-11-044505-3

EPUB ISBN 978-3-11-043611-2

Date of Publication: November 2018

Language of Publication: English

Subjects:

Electrical Engineering, Energy Engineering

Of interest to: Scientists, R\&D workers in industry, students in relevant master's level programs

For more information:

www.degruyter.com/books/978-3-11-044505-3 